\title{
PRELIMINARY CHARACTERIZATION AND IDENTIFICATION OF GRAM POSITIVE HEMOLYSIS BACTERIA
}

\author{
${ }^{1}$ Ahmed T. Almwafy*, Mohammed G. Barghoth, ${ }^{1}$ Said E. Desouky, Mohamed Roushdy \\ ${ }^{1}$ Department of Botany and Microbiology, Faculty of Science (Boys), Al-azhar \\ University, Cairo, Egypt.
}

*corresponding author:ahmed.tarek.201@azhar.edu.eg

\begin{abstract}
:
One of the most important pathogens that threaten human health all over the world is Staphylococcus spp. characterization and identification of such pathogen considers a useful tool to control of some serious problems resulting by these bacteria. Therefore one hundred and twenty samples including blood, urine, abscess, semen, pus, sputum, ears, vaginal and spit swabs were collected from patients of Tanta University Hospital and outpatient clinics. A total of 126 Gram positive bacterial isolates were obtained from these clinical specimens. Of these isolates 107 bacterial strains were identified as Staphylococcus spp and 15 strains identified as Streptococcus spp in addition to 4 strains were identified as Enterococcus spp, preliminary identification was conducted on the basis of colony characteristics such as Gram staining, pigment production, hemolysis, catalase activity, coagulase test and fermentation of manitol sugar. Out of these strains, $30.95 \%$ have the potency to make alpha hemolysis while $30.95 \%$ have the ability to make beta hemolysis and $38.09 \%$ posse the capacity to make gamma hemolysis on blood agar medium. Beta hemolysis Staphylococcus spp were selected for study of some virulence factors on basis of coagulase production in which $17.24 \%$ of Staphylococcus spp were coagulase positive and $82.76 \%$ were coagulase negative Staphylococcus spp. Studying the susceptibility pattern of these strains to some commercial antibiotics was carried out. Further future studies are recommended to investigate the effect of some natural compounds on gene regulation that responsible for hemolysis process.
\end{abstract}

Keywords: Hemolysis- Gram positive bacteria- Staphylococcus- Coagulase production 


\section{Introduction}

One of the most important Gram positive medical bacteria is Staphylococcus aureus. Its opportunistic pathogens for human and animal responsible for fatal disease like nosocomial and community-associated infections which make high morbidity and mortality rate. S. aureus can cause diseases ranging from soft tissue infections and minor skin to life-threatening invasive diseases such as osteomyelitis, endocarditis, septicemia, and pneumonia (Al-mebairik et al., 2016).

S. aureus attachment to tissue then invading it as well as avoiding host immune response through its virulence factors (Gnanamani et al., 2017). The difference of site of infection by $S$ aureus tend to the diversity of virulence factors and its ability to adaptation to different environments in the human host (Tuchscherr et al., 2019).

S. aureus appear as large yellow or white colonies on nutrient rich agar media. This pathogen can produce carotenoid pigments which imparts the yellow color on its colonies, so the term aureus refers to Latin word the color of gold. This yellow pigments act as antioxidant that protect this strain from the host's immune system. The organism also has the ability to produce different type of hemolysis like alpha, beta, gamma and delta.Several exotoxins can be secreted by this organism like coagulase , enterotoxins, toxic shock syndrome toxin-1 (TSST-1), and protein A. The medical importance of this strain is due to production of virulence factors, surface proteins, enzymes, toxins and biofilm formation in addition to rapid development of drug resistance (Abu-elghait 2016)-Bacterial resistance to antibiotics is an issue that has led to the search for new antibacterial approaches. Drugs targeting virulence is an alternative approach to treat infections with resistant bacteria (Escaich, 2008).

The ability of its transferring from person to surrounding area or another person makes it widespread pathogen (Michael \& Roberts, 2016). Therefore, billions of dollars are consuming every year by several countries such as the United States to control the infections that caused by this pathogen (Al-mebairik. 2016). Hence this study is aimed to isolation, characterization and identification of some hemolytic gram positive bacteria specially $S$. aureus from different localities of Egypt.

\section{MATERIALS AND METHODS}

\section{Samples collection}

A total of 120 samples were collected from different clinical specimens as the following ; blood, abscess, pus, sputum, urine, wound swabs, vaginal swabs and cerebral spinal fluid from inpatient and outpatient of Tanta University Hospital through November 2017 to march 2018(Karmakar et al., 2015)( Biswas et al.,2016) 


\section{Trypticase Soy Agar (TSA)}

This media is used for cultivation and isolation of fastidious and nonfastidious microorganisms. This medium is composed of pancreatic digest of casein (a peptone) 15 $\mathrm{gll}$, enzymatic digest of soybean $5 \mathrm{~g} \backslash$, sodium chloride $5 \mathrm{~g} \backslash$, agar $15.0 \mathrm{gll}$ and finally $\mathrm{pH}$ was adjusted at $7.3 \pm 0.2$ (Orth et al., 1993),( Curry et al.,1993).

\section{Blood Agar medium}

Blood agar medium is a highly enriched medium so it preferred for fastidious organisms and also often used to distinguish between pathogenic bacteria via determining the presence or absence of hemolysis and its type on red blood cells (Turista et al., 2019). The composition of this medium is peptone $10 \mathrm{~g} / \mathrm{l}$, Tryptose $10 \mathrm{~g} / \mathrm{l}$, Sodium chloride 5g/l, Agar $15 \mathrm{~g} / \mathrm{l}$ and $\mathrm{pH}$ was adjusted at 7.3 \pm 0.2 . Preparation of this medium is by adding 40 gram of dehydrated medium to 1 liter of distilled water then autoclaving for $15 \mathrm{~min}$ at $121^{\circ} \mathrm{C}$ after that let it to cool to $45^{\circ} \mathrm{C}$ and add $5 \%$ v/v sterile defibrinated sheep blood or human blood to sterile media then mix vigorously (Yeh $\boldsymbol{e t}$ al., 2009).

\section{Manitol Salt Agar (MSA)}

Manitol Salt Agar considers as an excellent medium for isolating staphylococci from heavy contaminated cultures in which coagulase positive staphylococci appear on this medium as a yellow colonies with yellow zone and coagulase negative staphylococci appear as a small red colonies without any change of the color of the medium while Micrococcus colonies will seem as a white to orange colonies and also with no change in medium color, on the other side any different strain will not grow on MSA.The MSA is consist of; pancreatic digest of casein $5.0 \mathrm{~g} / \mathrm{l}$, Peptic Digest of Animal Tissue $5.0 \mathrm{~g} / \mathrm{l}$, beef extract $1.0 \mathrm{~g} / \mathrm{l}$, sodium chloride $75.0 \mathrm{~g} / \mathrm{l}, \mathrm{D}$-mannitol10.0 g/l, phenol red $25.0 \mathrm{mg} / \mathrm{l}$ and agar15.0 g/l (Interim et al., 2016)

\section{Mueller Hinton Agar and Antibiotic susceptibility assay}

This medium is ideal for antibiotic susceptibility test (disk diffusion method). Its composed of Beef Extract $2.0 \mathrm{~g} / \mathrm{l}$, acid hydrolysate of casein $17.5 \mathrm{~g} / \mathrm{l}$, starch $1.5 \mathrm{~g} / \mathrm{L}$ and agar $17.0 \mathrm{~g} / \mathrm{l}$. Final $\mathrm{pH}$ should be adjusted at $7.3 \pm 0.3$ (Mueller et al., 1941), ( Washington et al., 1995),(Clinical and Laboratory Standards Institute, 2009).

the susceptibility to specified antibiotic is determined by measuring the clear zone around its disc on the plate. The result falls into three categories; resistant, intermediate, and susceptible. The antibiotics were used in our study were gentamicin $(10 \mu \mathrm{g})$, erythromycin $(15 \mu \mathrm{g})$, oxacillin $(1 \mu \mathrm{g})$, ciprofloxacin $(5 \mu \mathrm{g})$, ampicillin $(10 \mu \mathrm{g})$, linezolid $(30 \mu \mathrm{g})$ clindamycin $(2 \mu \mathrm{g})$, vancomycin $(30 \mu \mathrm{g})$, teicoplanin, $(30 \mu \mathrm{g})$ and doxycycline $(30 \mu \mathrm{g})$ (Kulkarni et al., 2019),(Garg et al., 2019).

\section{Phenotypic Identification of Staphylococcus spp.}

The identification of Staphylococcus strains were performed on the basis of Standard microbiological methods including colony characteristics, Gram staining, 
pigment production, hemolysis and the following biochemical reactions, catalase activity, coagulase test (human plasma) and manitol fermentation, finally the most potent isolates was identifying by a full biochemical tests through BIOMERIEUX VITEK2 SYSTEM (Desouky et al., 2014).

\section{Catalase test}

Catalase test was conducted to detect the ability of bacteria to produce catalase enzyme through three common methods; the slide test method, the tube or bottle method and the agar slant method, during this test slide tube method was applied by adding 1 drop of $3 \% \mathrm{H}_{2} \mathrm{O}_{2}$, theoretically the catalase enzyme will accelerate the breakdown the hydrogen peroxide into water and oxygen (Reine\& Karen, 2010) .

\section{Oxidase test}

This test was applied on a catalase positive isolates to detect the capability of these isolates to secrete oxidase enzyme. This test theoretically based on the presence of indophenol oxidase enzyme which catalyzes the electron transportation from donor compounds (NADH) to electron acceptors (usually oxygen) (Shields et al,. 2016) .

\section{Coagulase Test}

This test was performed to detect the presence of coagulase enzyme which able to convert plasma fibrinogen to fibrin causing agglutinates or a clot. There are two types of coagulase; bound coagulase which is bounded to cell wall and free coagulase which is liberated by cell wall. This test used mainly to distinguish $S$. aureus strains from other different Staphylococcus strains (Desouky et al., 2014).

\section{Hemolysin Production}

Qualitative hemolysis assay were completed on blood base agar medium supplemented with 5\% sheep blood and the samples were one of three forms, the first form was a clear zone around the colonies which distinguished by its transparency because a complete lysis of red blood cells, these isolates recorded as a $\beta$ hemolytic isolates. The second form was a brownish green color zone around colonies and this discoloration of the medium color was because the isolates could reduce the hemoglobin of red blood cells to methemoglobin which distinguished by a brownish green color, these isolates was recorded as $\alpha$ hemolytic isolates. The third form was no change in medium color so these isolates recoded as a $\gamma$ hemolytic isolates (Buxton \& Rebecca 2016), (Divyakolu et al,. 2019).

Quantitative hemolysis assay were applied according to Cho and his co-team on only a coagulase, catalase and manitol salt fermentation positive isolates which recorded as a $\beta$ hemolytic isolates and distinguished with a cluster shape under microscope (Cho et al., 2015). S. aureus culture were diluted at 1:100 with TSB culture media and incubated at $37^{\circ} \mathrm{C}$ for 16 hours under shaking condition at $250 \mathrm{rpm}$. Human red blood cells separated by centrifugation at $900 \mathrm{xg}$ for $5 \mathrm{~min}$, then human red blood cells washed three times with PBS buffer and diluted at 3\% of red blood cells in PBS buffer, after 
that the cell culture $50 \mu$ were added, the mixture were incubated under shaking condition at $250 \mathrm{rpm}$ at $37^{\circ} \mathrm{C}$ for 1 hour. S. aureus (ATCC 29213) were used as a positive control and the negative control inoculated with PBS buffer instead of the organism. the optical density was measured at $543 \mathrm{~nm}$ after supernatant collection by centrifugation at 16,600xg for $10 \mathrm{~min}$ (Guo et al., 2019),(Tang et al., 2019).

\section{RESULTS AND DISCUSSION}

A total of 126 gram positive bacterial isolates were obtained from several clinical specimens that collected from different sources. Of these isolates 107 (85\%) bacterial strains were preliminary identified as Staphylococcus spp and 15 (12\%) strains identified as Streptococcus spp in addition to $4(3 \%)$ strains were identified as Enterococcus spp. The higher percent of Staphylococcus spp. occurrence that isolated from clinical samples indicates on the higher transition rate of this bacteria hospital community and different medical tools and this reflected the importance of studying of this type of microorganism as described by (Desouky et al., 2014).

Bacterial identification was conducted on the basis of colony characteristics such as gram staining, pigment production, hemolysis, catalase activity, coagulase test and fermentation of manitol sugar. Gram stain is used to help in differentiating between gram positive cocci strains. All bacteria isolated during this study are gram positive, hence the cell arrangement is required to differentiate between these genera in which some bacteria like staphylococci commonly divide on random planes to form grapelike clusters shape while other divide in one plane form pairs or chains and this arrangement commonly observed by Streptococcus and Enterococcus. As well as catalase and oxidase activity are aid in differentiating between gram positive genera because Streptococcus and Enterococcus are negative for both testes while Staphylococcus spp. are positive for the same testes. The highest number of Staphylococcus strains were isolated from female which represented as 12 strains $(41.38 \%)$ and then from male represented as 10 strains $(34.48 \%)$, on the other hand the lowest number of strains were founded in babies and child and represented as $6(20.69 \%)$ and $1(3.45 \%)$, respectively as showed in Fig1 and this may be refers to that females are the most type exhibited to Staphylococcus spp. risks.

Staphylococcus strains were collected from several clinical specimens and the higher number of this strain was isolated from automated blood cultures and then from sputum and finally from urine with percentage $48.28 \%$ (14 strains), $17.24 \%$ (5 strains) and $13.79 \%$ (4 strains), respectively, while the lower number of this strain was collected from pus, trachea, manual blood cultures, ascetic fluid cultures, Pleural fluid with ratio $6.91 \%$ (2 strains) and 3.45\% (1strain) for the other sources respectively as represented in Fig 2. The predominance of the isolation Staphylococcus strains from blood cultures indicates the need for the more bacteriological examination in this source, because of the infection that may by cause by these strains and reach to this source.

In the present study some virulence factors are studied which consider as correlated tools to pathogenicity caused by this bacteria as noted by (Koneman et al., 1988), (Otto, 2004), (Lee et al., 2012). In which $30.95 \%$ (39 strains) have the potency to make alpha hemolysis while $30.95 \%$ (39 strains) have the ability to make beta hemolysis and 
$38.09 \%$ (48 strains) posse the capacity to make gamma hemolysis on blood agar medium.

The pathogenesis of $S$. aureus infections depends on the production of surface proteins that mediate bacterial adherence to host tissues, secretion of a series of extracellular toxins, and enzymes that destruct host cells and tissues, avoidance of, or incapacitating, the host immune defense, and growth and spread of bacteria in host cells as mention by (Lowy, 1998). Add to that the most important virulence factor in Staphylococcus spp. is hemolysins that damage the host cells by making pores in it as recorded by (Dinges $e t$ al., 2000). Staphylococcus strains were selected for study of some virulence factors based on their coagulase activity which differentiated into 5 isolates (17.24\%) were Staphylococcus spp. coagulase positive while 24 isolates $(82.76 \%)$ were coagulase negative Staphylococcus spp. Primary description of these isolates was illustrated in table 1 and their coagulase activity was showed in Fig 3.

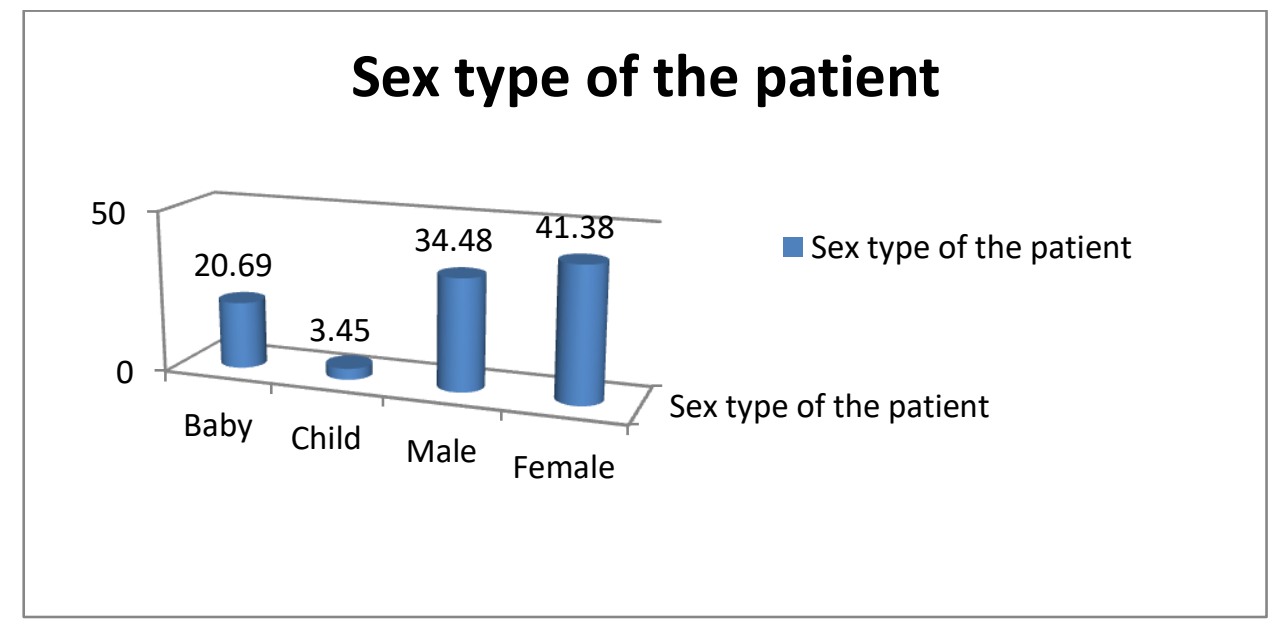

Fig 1: Percentage of Staphylococcus strains related to different patient sex.

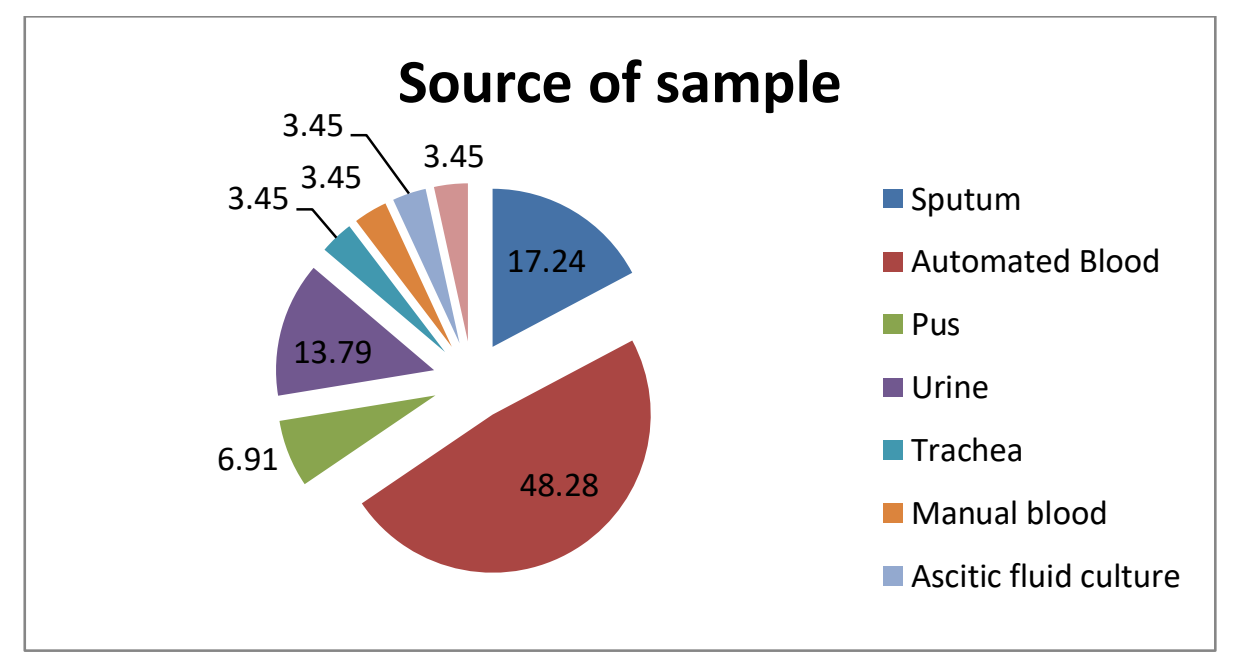

Fig 2: Percentage of Staphylococcus strains related to different sample collection sources. 


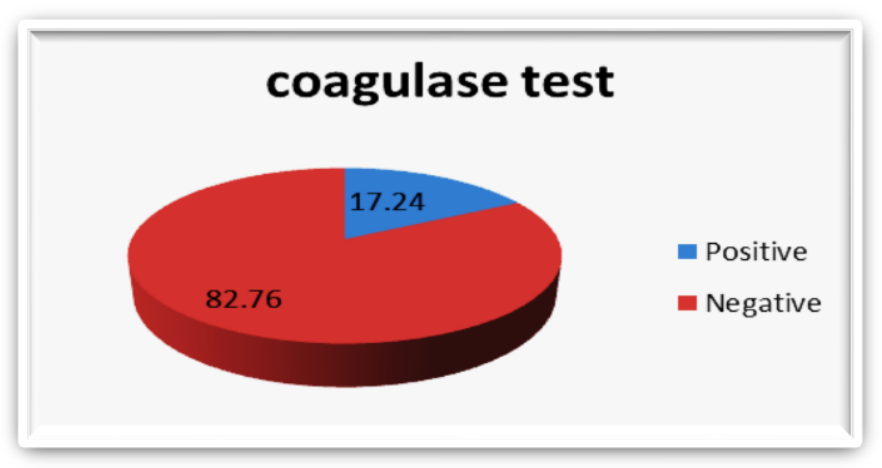

Fig3: Percentage of coagulase positive and coagulase negative between Staphylococcus spp. Isolated from different source and sex.

Table 1: primary description of Staphylococcus spp. strains from the collected samples related to their sources and sex

\begin{tabular}{|c|c|c|c|c|c|c|}
\hline $\begin{array}{c}\text { Sample } \\
\text { code }\end{array}$ & $\begin{array}{l}\text { Sex } \\
\text { type }\end{array}$ & Sample source & $\begin{array}{c}\text { Color on } \\
\text { MSA }\end{array}$ & $\begin{array}{c}\text { Coagulase } \\
\text { test }\end{array}$ & Catalase test & $\begin{array}{c}\text { Gram } \\
\text { stain/shape }\end{array}$ \\
\hline I1 & $\mathrm{M}$ & Spit culture & Yellow & Negative & Positive & +ve cocci \\
\hline I58 & M & Sputum & Yellow & Negative & Positive & +ve cocci \\
\hline I76 & M & Blood & Yellow & Negative & Positive & +ve cocci \\
\hline $\mathrm{O} 41$ & Baby & Blood & Red- Yellow & Negative & Positive & +ve cocci \\
\hline O80 & $\mathrm{F}$ & Blood & Yellow & Negative & Positive & +ve cocci \\
\hline I73 & $\mathrm{F}$ & Sputum & Yellow & Negative & Positive & +ve cocci \\
\hline O93 & $\mathrm{F}$ & Pus & Yellow & Positive & Positive & +ve cocci \\
\hline I111 & $\mathrm{M}$ & Trachea & Yellow & Negative & Positive & +ve cocci \\
\hline O46 & $\mathrm{M}$ & Urine & Yellow & Negative & Positive & +ve cocci \\
\hline I49 & $\mathrm{M}$ & Urine & Yellow & Positive & Positive & +ve cocci \\
\hline I103 & $\mathrm{M}$ & Urine & Red- Yellow & Negative & Positive & +ve cocci \\
\hline $\mathrm{O} 40$ & $\mathrm{~F}$ & Blood & Red- Yellow & Negative & Positive & +ve cocci \\
\hline O64 & Baby & Blood & Yellow & Negative & Positive & +ve cocci \\
\hline I82 & $\mathrm{F}$ & Sputum & Yellow & Positive & Positive & +ve cocci \\
\hline I104 & $\mathrm{F}$ & Sputum & Yellow & Negative & Positive & +ve cocci \\
\hline I53 & Baby & Blood & Yellow & Positive & Positive & +ve cocci \\
\hline $\mathrm{O} 75$ & $\mathrm{~F}$ & Blood & Yellow & Negative & Positive & +ve cocci \\
\hline O88 & M & Blood & Yellow & Negative & Positive & +ve cocci \\
\hline 015 & $\mathrm{~F}$ & Urine & Yellow & Negative & Positive & +ve cocci \\
\hline O54 & Child & Pus & Yellow & Negative & Positive & +ve cocci \\
\hline O83 & $\mathrm{F}$ & Blood & Yellow & Negative & Positive & +ve cocci \\
\hline $\mathrm{O} 44$ & M & Blood & Red- Yellow & Negative & Positive & +ve cocci \\
\hline O85 & Baby & Blood & Yellow & Negative & Positive & +ve cocci \\
\hline O114 & $\mathrm{F}$ & Blood & Yellow & Negative & Positive & +ve cocci \\
\hline O79 & $\mathrm{F}$ & Blood & Yellow & Negative & Positive & +ve cocci \\
\hline $\mathrm{O} 122$ & Baby & Blood & Yellow & Positive & Positive & +ve cocci \\
\hline I52 & $\mathrm{F}$ & Ascetic fluid & Yellow & Negative & Positive & +ve cocci \\
\hline O126 & Baby & Blood & Red- Yellow & Negative & Positive & +ve cocci \\
\hline O66 & $\mathrm{M}$ & pleural fluid & Yellow & Negative & Positive & +ve cocci \\
\hline
\end{tabular}


The most potent strains are selected based on the ability of strain to make complete blood hemolysis (beta hemolysins) through produce an important virulence factor $\alpha$ hemolysin protein with different degrees detected quantitatively by spectrophotometer 543nm as described by (Desouky et al., 2014) by using S. aureus ATCC 29213 as positive control, clinical isolate S. aureus I82 and S. aureus 0122 exhibit the most hemolysin producing strains as observed in table 2 and Fig 4. Strain I82 produced hemolysin near three times approximately while strain $\mathrm{O} 122$ produced one and half time than positive control strain, therefore both $S$. aureus strains that used in this study exhibited more hemolysin efficiency than any strains reported by Desouky and his team during quantitative detection of hemolysin production by threeteen $S$. aureus strains (Desouky et al., 2014)

Table 2: Hemolysis degree for most potent strains producing hemolysis by quantitative method

\begin{tabular}{ccc}
\hline Sample No. & O.D: $543 \mathrm{~nm}$ & Relative hemolysis \% \\
\hline$+\mathrm{Ve}$ & 1.069 & 100 \\
$-\mathrm{Ve}$ & 0.052 & 4.86 \\
82 & 3.010 & 281.57 \\
122 & 1.781 & 166.6
\end{tabular}

O.D; Optical Density, P; Positive, N; Negative

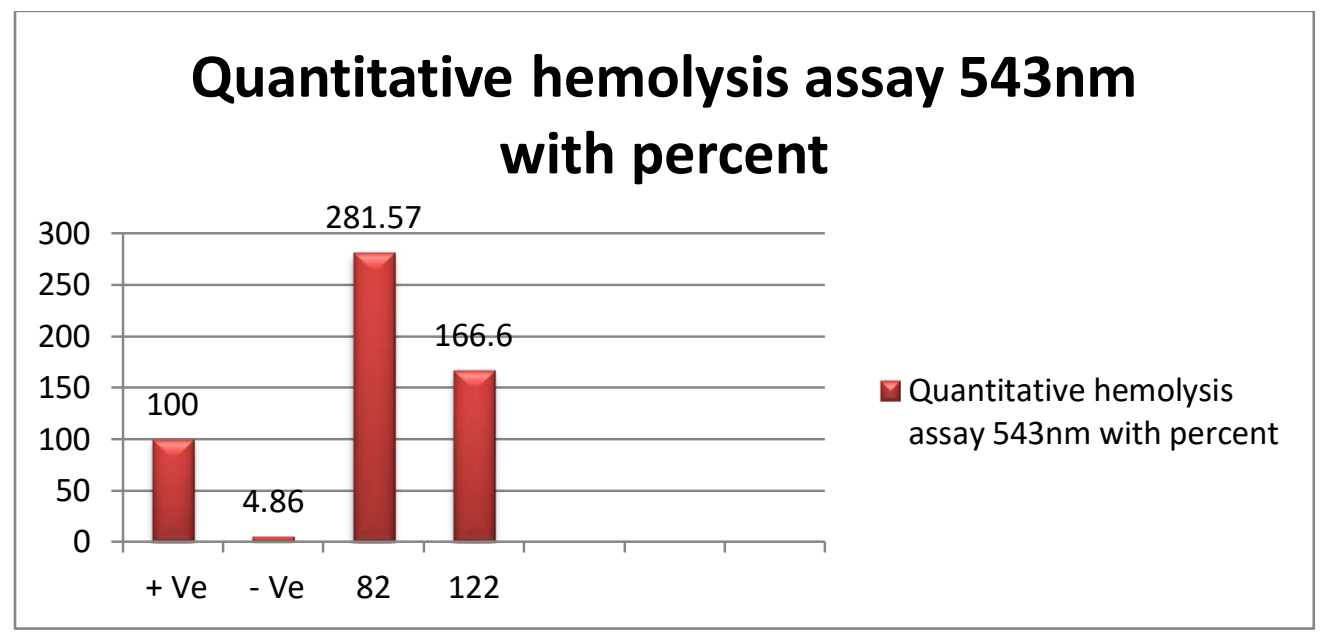

Fig 4: The quantitative hemolysis assay for the most potent strains

Identification of the most potent isolates I82 and O122 were accomplished by BIOMERIEUX VITEK2 SYSTEM in which the isolated I82 was correlated with strain Staphylococcus aureus that has bio-number (010402026632231) with high similarity reached to $94 \%$ and hence this strain identified as staphylococcus aureus I82 while the other strain $\mathrm{O} 122$ was related to staphylococcus warneri strain that has bio-number (010002073661031) with similarity $90 \%$ and hence this strain well known as Staphylococcus warneri O122. All morphological, physiological and biochemical characterizations recorded by VITEK2 SYSTEM are shown in table 3. 


\begin{tabular}{|c|c|c|c|}
\hline \multicolumn{2}{|l|}{ Characterization } & \multicolumn{2}{|l|}{ Strains } \\
\hline \multicolumn{2}{|l|}{ Morphological characteristics } & I82 & O122 \\
\hline \multicolumn{2}{|l|}{ Color } & Golden yellow & Golden yellow \\
\hline \multicolumn{2}{|l|}{ Gram-reaction } & + & + \\
\hline \multicolumn{2}{|l|}{ Catalase } & + & + \\
\hline \multirow{2}{*}{\multicolumn{2}{|c|}{ Coagulase plasma reaction }} & + & + \\
\hline & \\
\hline \multicolumn{2}{|c|}{ D-Amygdalin Phosphatidylinositol (AMY) } & - & - \\
\hline phospholipase C & PIPLC & - & - \\
\hline D-xylose & dXYL & - & - \\
\hline Arginine dihydrolase I & $\mathrm{ADH} \mathrm{I}$ & + & + \\
\hline Beta-Galactosidase & BGAL & _ & _ \\
\hline Alpha-Glucosidase & AGLU & - & - \\
\hline Ala-Phe-Pro Arylamidase & APPA & - & - \\
\hline Cyclodextrin & CDEX & - & - \\
\hline L-Aspartate Arylamidase & AspA & _ & _ \\
\hline Beta-Galactopyranosidase & BGAR & $\overline{-}$ & $\overline{-}$ \\
\hline Alpha-Mannosidase & AMAN & - & - \\
\hline Phosphatase & PHOS & - & + \\
\hline Leucine ARYLAMIDASE & LeuA & - & - \\
\hline L-Proline ARYLAMIDASE & ProA & - & - \\
\hline BETA GLUCURONIDASE & BGURr & - & - \\
\hline \multicolumn{2}{|c|}{ ALPHA-GALACTOSIDASE L-Pyrrolidonyl } & - & - \\
\hline ARYLAMIDASE & PyrA & + & + \\
\hline BETA-GLUCURONIDASE & BGUR & - & - \\
\hline Alanine ARYLAMIDASE & AlaA & - & - \\
\hline Tyrosine ARYLAMIDASE & TyrA & - & - \\
\hline D-SORBITOL & dSOR & - & - \\
\hline UREASE & URE & + & + \\
\hline POLYMIXIN B RESISTANCE & E POLYB & + & + \\
\hline D-GALACTOSE & & + & + \\
\hline D-RIBOSE & dRIB & - & + \\
\hline L-LACTATE alkalinization & ILATk & + & + \\
\hline LACTOSE & LAC & - & - \\
\hline D-MALTOSE & dMAL & + & + \\
\hline BACITRACIN RESISTANCE & BACI & + & + \\
\hline NOVOBIOCIN RESISTANCE & E NOVO & - & - \\
\hline GROWTH IN $6.5 \%$ Nacl & NC6.5 & + & + \\
\hline D-MANNITOL & dMAN & + & + \\
\hline D-MANNOSE METHYL-B-D & $(\mathrm{dMNE})$ & & \\
\hline Continue & & + & + \\
\hline GLUCOPYRANOSIDE & MBdG & + & - \\
\hline PULLULAN & PUL & - & - \\
\hline D-RAFFINOSE & dRAF & - & - \\
\hline O/129 RESISTANCE & O129R & + & - \\
\hline SALICIN & SAL & + & + \\
\hline SACCHAROSE/SUCROSE & SAC & + & + \\
\hline D-TREHALOSE & dTRE & - & - \\
\hline ARGININE DIHYDrolase 2 & $\mathrm{ADH} 2 \mathrm{~s}$ & & \\
\hline OPTOCHIN RESISTANCE & & + & + \\
\hline
\end{tabular}
+: POSTIVE Result, - ;Negative Result

The antibiotic susceptibility test for the most potent isolates was conducted with different commercial antibiotics agents such as gentamicin $(10 \mu \mathrm{g})$, erythromycin $(15 \mu \mathrm{g})$, oxacillin $(1 \mu \mathrm{g})$, ciprofloxacin $(5 \mu \mathrm{g})$, ampicillin $(10 \mu \mathrm{g})$, linezolid $(30 \mu \mathrm{g})$, clindamycin $(2 \mu \mathrm{g})$, vancomycin $(30 \mu \mathrm{g})$, teicoplanin $(30 \mu \mathrm{g})$ and doxycycline $(30 \mu \mathrm{g})$ 
as represented in table 4.The clinical efficacy of antibacterial agents including bacteriostatic or bactericidal effects that used for the treatment of $S$. aureus infections should depend on the ability of this antibiotic to prevent the virulence factors produced by such bacteria. For the management of toxic $S$. aureus infections, some antibiotics display an anti-virulence activity at different concentrations. For instance, protein synthesis-suppressing antibiotics, such as clindamycin and linezolid, are recommended for the treatment of $S$. aureus-produced toxic syndromes, as concentrations below the MIC have been shown to impair the expression of $S$. aureus virulence factors (Herbert et al., 2001), (Bernardo et al., 2004).

Table 4: Antibiotics susceptibility test for the most potent isolates

\begin{tabular}{lccc}
\hline Antibiotics & Abbreviation & S. aureus I82 & S. warneri O122 \\
\hline Gentamicin $(10 \mu \mathrm{g})$ & CN10 & $\mathrm{R}$ & $\mathrm{R}$ \\
Erythromycin $(15 \mu \mathrm{g})$ & $\mathrm{E} 15$ & $\mathrm{R}$ & $\mathrm{S}$ \\
Oxacillin $(1 \mu \mathrm{g})$ & $\mathrm{OX} 1$ & $\mathrm{I}$ & $\mathrm{R}$ \\
Ciprofloxacin $(5 \mu \mathrm{g})$ & $\mathrm{CIP} 5$ & $\mathrm{I}$ & $\mathrm{R}$ \\
Ampicillin $(10 \mu \mathrm{g})$ & SAM20 & $\mathrm{R}$ & $\mathrm{R}$ \\
Lnezolid $(30 \mu \mathrm{g})$ & $\mathrm{LZD}-30$ & $\mathrm{~S}$ & $\mathrm{R}$ \\
Clindamycin $(2 \mu \mathrm{g})$ & $\mathrm{DA} 2$ & $\mathrm{~S}$ & $\mathrm{R}$ \\
Vancomycin $(30 \mu \mathrm{g})$ & $\mathrm{VA30}$ & $\mathrm{S}$ & $\mathrm{S}$ \\
Teicoplanin $(30 \mu \mathrm{g})$ & TEC30 & $\mathrm{S}$ & $\mathrm{R}$ \\
Doxycycline $(30 \mu \mathrm{g})$ & $\mathrm{DO} 30$ & $\mathrm{R}$ & $\mathrm{I}$ \\
\hline
\end{tabular}

S; Sensitive, R; Resistant, I; Intermediate

Strain S. aureus I82 was showed the sensitivity toward 4 (40\%) of commercial antibiotics under test including linezolid $(30 \mu \mathrm{g})$, clindamycin $(2 \mu \mathrm{g})$, vancomycin $(30$ $\mu \mathrm{g})$ and teicoplanin $(30 \mu \mathrm{g})$ while the resistance was toward $4(40 \%)$ antibiotics represent in ampicillin $(10 \mu \mathrm{g})$, gentamicin $(10 \mu \mathrm{g})$, erythromycin $(15 \mu \mathrm{g})$ and doxycycline $(30 \mu \mathrm{g})$, finally strain $S$. aureus I82 was given intermediate response to oxacillin $(1 \mu \mathrm{g})$ and ciprofloxacin $(5 \mu \mathrm{g})$. On the contrary $S$. warneri $\mathrm{O} 122$ strain was showed $70 \%$ (7) resistance for this antibiotics including gentamicin $(10 \mu \mathrm{g})$, oxacillin $(1 \mu \mathrm{g})$, ciprofloxacin $(5 \mu \mathrm{g})$, ampicillin $(10 \mu \mathrm{g})$, linezolid $(30 \mu \mathrm{g})$, clindamycin $(2 \mu \mathrm{g})$ and teicoplanin $(30 \mu \mathrm{g})$, also this strain showed intermediate response to one antibiotcs $(10 \%)$ doxycycline $(30 \mu \mathrm{g})$ while the sensitivity was founded toward $20 \%$ (2) erythromycin $(15 \mu \mathrm{g})$ and vancomycin $(30 \mu \mathrm{g})$ as represent in Fig 5.

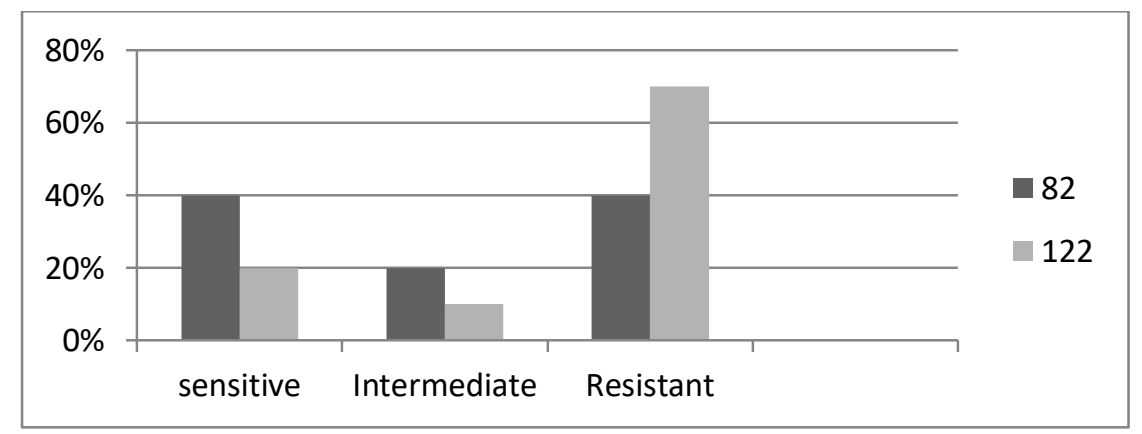

Fig5: The susceptibility test for the most potent isolates toward antibiotic. 
The result concluded from this test indicated that the most effective antibiotic that should be used toward the infection caused by S. aureus I 82 and S. warneri O 122 strains is vancomycin $(30 \mu \mathrm{g})$. But it's must be known that for many years later and with the abuse of traditional antibacterial agents addition to the decrease of the development of new antibacterial agents, combined with increasing numbers of $S$. aureus strains have become Methicillin Resistant Staphylococcus aureus (MSRA) strains, which are spread in communities, leading to dramatic changes in epidemiology and disease incidence during over the world. Consequently, the investigation of new therapeutic agents to avoid the multidrug resistance of Staphylococcus spp. was recommended particularly by using some natural compounds upon the level of gene regulation to control in such pathogens.

\section{REFRENCES:}

Al-Mebairik, N. F., El-Kersh, T. A., Al-Sheikh, Y. A., \& Marie, M. A. M. (2016). A review of virulence factors, pathogenesis, and antibiotic resistance in Staphylococcus aureus. Reviews in Medical Microbiology, 27(2), 50-56.

Bernardo, K.; Pakulat, N.; Fleer, S.; Schnaith, A.; Utermohlen, O.; Krut, O.; Muller, S.; Kronke, M(2004). Subinhibitory concentrations of linezolid reduce Staphylococcus aureus virulence factor expression. Antimicrob. Agents Chemother., 48, 546-555.

Biswas, S., Karmakar, A., \& Ghosh, C. (2015). Multidrug resistant pathogenic Staphylococcus aureus in the pimples. Medical Science [Internet], 16, 41-50.

Buxton, $\boldsymbol{R}$. (2005). Blood agar plates and hemolysis protocols. American Society for Microbiology.

Cho, H. S., Lee, J. H., Cho, M. H., \& Lee, J. (2015). Red wines and flavonoids diminish Staphylococcus aureus virulence with anti-biofilm and anti-hemolytic activities. Biofouling, 31(1), 1-11.

Clinical and Laboratory Standards Institute. (2009). Performance standards for antimicrobial susceptibility testing of anaerobic bacteria: informational supplement. Clinical and Laboratory Standards Institute (CLSI).

Curry, A. S., Joyce, G. G., \& McEwen Jr, G. N. (1993). CTFA Microbiology guidelines. The Cosmetic, Toiletry, and Fragrance Association. Inc. Washington, DC.

Desouky, S. E., El-Gamal, M. S., Mohammed, A. F., \& Abu-Elghait, M. A. (2014). Determination of some virulence factors in Staphylococcus spp. isolated from clinical samples of different Egyptian patients. World Applied Sciences Journal, 32(4), 731-740.

Dinges,M.M., P.M. Orwin and P.M. Schlievert, (2000). Exotoxins of Staphylococcus aureus. Clin. Microbiol.Rev., 13: 16-34. 
Divyakolu, S., Chikkala, R., Ratnakar, K. S., \& Sritharan, V. (2019). Hemolysins of Staphylococcus aureus - An Update on Their Biology, Role in Pathogenesis and as Targets for Anti-Virulence Therapy. Advances in Infectious Diseases, 9(2), 80-104.

Escaich, S. (2008). Antivirulence as a new antibacterial approach for chemotherapy. Current opinion in chemical biology, 12(4), 400-408.

Garg, V. K., Mishra, S., Gupta, N., Garg, R., Sachidanand, B., Vinod, K., ... \& Bhatnagar, S. (2019). Microbial and Antibiotic Susceptibility Profile among Isolates of Clinical Samples of Cancer Patients Admitted in the Intensive Care Unit at Regional Tertiary Care Cancer Center: A Retrospective Observational Study. Indian journal of critical care medicine: peer-reviewed, official publication of Indian Society of Critical Care Medicine, 23(2), 67.

Gnanamani, A., Hariharan, P., \& Paul-Satyaseela, M. (2017). Staphylococcus aureus: Overview of bacteriology, clinical diseases, epidemiology, antibiotic resistance and therapeutic approach. Frontiers in Staphylococcus aureus, 4-28.

Guo, N., Liu, Z., Yan, Z., Liu, Z., Hao, K., Liu, C., \& Wang, J. (2019). Subinhibitory concentrations of Honokiol reduce $\alpha$-Hemolysin (Hla) secretion by Staphylococcus aureus and the Hla-induced inflammatory response by inactivating the NLRP3 inflammasome. Emerging microbes \& infections, 8(1), 707-716.

Herbert, S.; Barry, P.; Novick, R.P. (2001). Subinhibitory clindamycin differentially inhibits transcription of exoprotein genes in Staphylococcus aureus. Infect. Immun., 69, 2996-3003.

Interim, S., Announcement, R., Examination, M., Nonsterile, O. F., \& Specifie, T. F. O. R. (2016). Microbiological Examination of Nonsterile Products: Microbial Enumeration Tests 61 . 34(6), 1-12.

Karmakar, A., Dua, P., \& Ghosh, C. (2016). Biochemical and molecular analysis of Staphylococcus aureus clinical isolates from hospitalized patients. Canadian journal of infectious diseases and medical microbiology, 2016.

Koneman, E.W., S.D. Allen, V.R. Dowell and H.M. Sommer, (1988). Diagnostic Microbiology. Chapter 9, 5th ed., J.B. Lippincott Co., Philadelphia, USA, pp: 539-576.

Kulkarni, A. P., Nagvekar, V. C., Veeraraghavan, B., Warrier, A. R., TS, D., Ahdal, J., \& Jain, R. (2019). Current Perspectives on Treatment of Gram-Positive Infections in India: What Is the Way Forward?. Interdisciplinary perspectives on infectious diseases, 2019.

Lee, J.H., J.H. Park, M.H. Cho and J. Lee,( 2012). Flavone Reduces the Production of Virulence Factors, Staphyloxanthin and -Hemolysin, in Staphylococcus aureus. 
Current Microbiology, 65: 726-732.

Lowy, F.D. Staphylococcus aureus infections. N. Engl. J. Med. (1998), 339, 520-532.

Michael, K. E., No, D., \& Roberts, M. C. (2016). Methicillin-resistant Staphylococcus aureus isolates from surfaces and personnel at a hospital laundry facility. Journal of applied microbiology, 121(3), 846-854.

Mueller, J. H., \& Hinton, J. (1941). A protein-free medium for primary isolation of the Gonococcus and Meningococcus. proceedings of the Society for Experimental Biology and Medicine, 48(1), 330-333.

Orth, D. S. (1993). Handbook of cosmetic microbiology. MARCEL DEKKER, INC., NEW YORK, NY(USA). 1993.

Otto, M., (2004). Virulence factors of the coagulase negative staphylococci. Front. Biosci., 9: 841-863.

Reiner, K. (2010). Catalase test protocol. American society for microbiology. 2-6, Catalase test procedures. (2010)

Richard Facklam and J. A. Elliott (1995). Identification, Classification, and Clinical Relevance of Catalase-Negative, Gram-Positive Cocci, Excluding the Streptococci and Enterococci. CLIN. MICROBIOL. REV. Vol. 8 (4) 479-495.

Shields, P., \& Cathcart, L. (2010). Oxidase test protocol . American Society for Microbiology, 6-9, Oxidase test procedures. (2010)

Tang, F., Li, L., Meng, X. M., Li, B., Wang, C. Q., Wang, S. Q.,\& Tian, Y. M. (2019). Inhibition of alpha-hemolysin expression by resveratrol attenuates Staphylococcus aureus virulence. Microbial pathogenesis, 127, 85-90.Testing, S. (2019). Susceptibility Testing.

Tuchscherr, L., Pöllath, C., Siegmund, A., Deinhardt-Emmer, S., Hoerr, V., Svensson, C. M., ... \& Löffler, B. (2019). Clinical S. aureus isolates vary in their virulence to promote adaptation to the host. Toxins, 11(3), 135.

Turista, D. D. R., \& Puspitasari, E. (2019). The Growth of Staphylococcus aureus in the blood agar plate media of sheep blood and human blood groups A, B, AB, and O. Jurnal Teknologi Laboratorium, 8(1), 1-7.

Washington, J. A., \& Woods, G. L. (1995). Antibacterial susceptibility tests: Dilution and disk diffusion methods. Manual of Clinical Microbiology. 6th ed. St. Louis: Mosby, 45-50.

Yeh, E., Pinsky, B. A., Banaei, N., \& Baron, E. J. (2009). Hair sheep blood, citrated or defibrinated, fulfills all requirements of blood agar for diagnostic microbiology laboratory tests. PloS one, 4(7). 


\title{
التوصيف الأولى والتعريف للبكتريا المسؤله عن انحلال الدم ولموجبه لصبغة جرام
}

\author{
أحمد طارق المو افى*-- محمد جمال برغوث - سعيد السيد دسوقى - محم رشدى \\ قسم النبات والميكروبيولوجي ـ كلية العلوم بنين - جامعة الأزهر - مدينة نصر ـ القاهرة - مصر \\ ahmed.tarek.201@azhar.edu.eg : البريد الاكتروني للباحث الرئيسي*
}

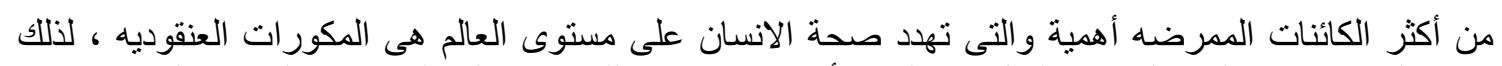

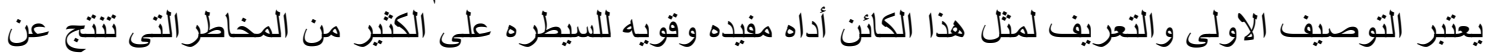

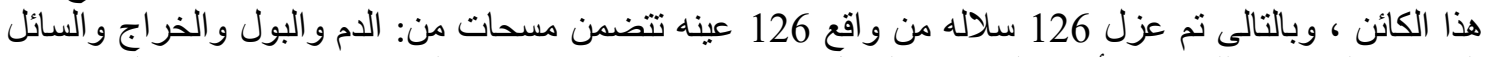

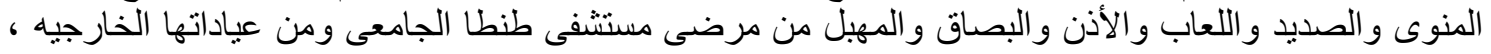

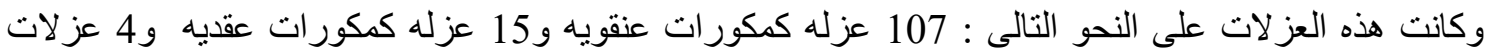

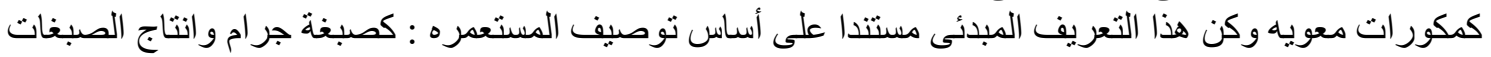

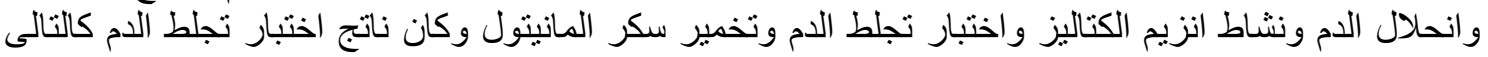

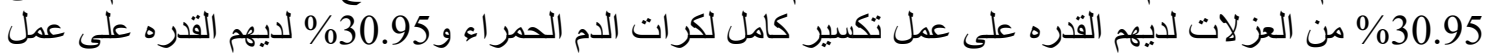

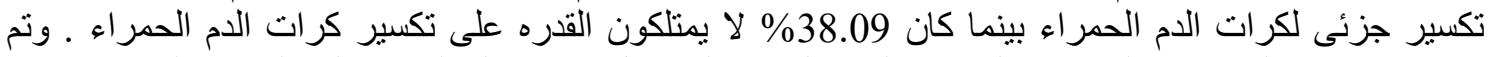

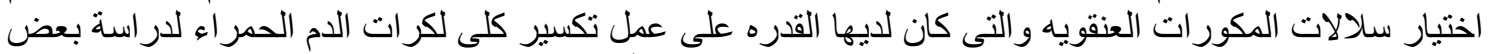

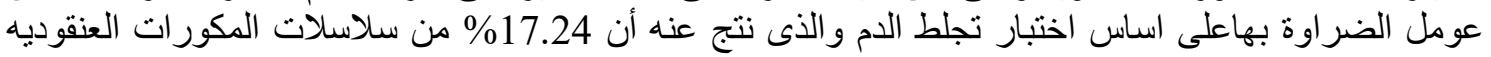

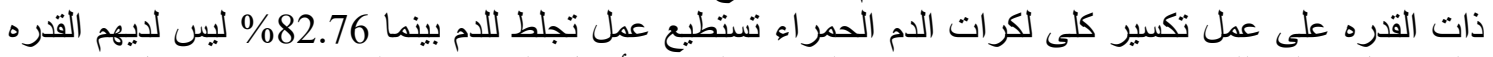

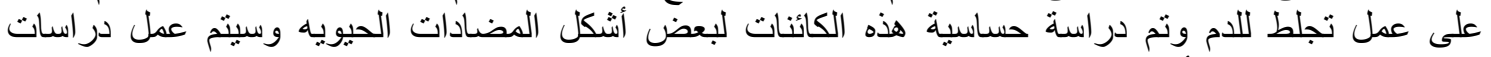

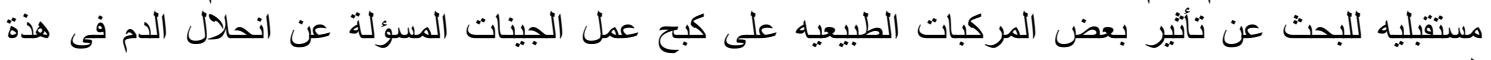
البكتريا.

الكلمات المفتاحية: انحلال الدم ـ بكتريا موجبة الجر ام ـ المكور ات العنقودية ـ إنتاج انزيم تجلط الدم 